\title{
Multiple Sclerosis: Current Knowledge and Future Outlook
}

\author{
Christian P. Kamm ${ }^{a}$ b Bernard M. Uitdehaag ${ }^{a} \quad$ Chris H. Polman ${ }^{a}$ \\ ${ }^{a}$ Department of Neurology, VU University Medical Center, Amsterdam, The Netherlands; \\ ${ }^{b}$ Department of Neurology, Inselspital, Bern University Hospital, and University of Bern, Bern, Switzerland
}

\section{Key Words}

Diagnostic criteria - Epidemiology · Multiple sclerosis .

Pathophysiology $\cdot$ Treatment of multiple sclerosis

\section{Abstract}

Background: Multiple sclerosis (MS) is a chronic inflammatory disease of the central nervous system characterized by demyelination and axonal loss. The etiology of MS is unknown; however, environmental and genetic factors play a key role in the development of MS. Diagnostic criteria have been adapted to facilitate earlier diagnosis with increased sensitivity and specificity. Our understanding of the pathophysiology of MS has deepened considerably in recent years, resulting in different therapies to modify the disease course. Furthermore, several drugs have lately shown efficacy in phase III studies and their approval is expected in the near future. As treatment options expand, a future challenge will be to find the optimal treatment for the individual patient. Summary: This mini-review gives an overview of the current knowledge of MS with emphasis on the latest diagnostic criteria and both current and upcoming treatment options. Key Messages: Treatment of MS changes rapidly as the knowl- edge and therapeutic options in MS expand. Clinical Impact: Diagnosis of MS is based on McDonald criteria. MS therapy can be divided into relapse, disease-modifying and symptomatic treatment. Relapses are commonly treated with intravenous methylprednisolone. First-line therapy consists of either interferon- $\beta$, glatiramer acetate or teriflunomide. In general, agents used as escalation therapies (natalizumab, fingolimod and mitoxantrone) are more potent than the agents used for first-line therapy; however, these have potentially serious side effects and should be used with care.

๑ 2014 S. Karger AG, Basel

\section{Epidemiology}

Multiple sclerosis (MS) is a chronic inflammatory disease of the central nervous system (CNS) and the most common cause of nontraumatic disability in young adults [1]. The incidence of MS is low in childhood and increases after the age of 18 , reaching a peak between 20 and 40 years (mean age of 30 years) with women being affected approximately 2-5 years earlier than men [2]. After-

\section{KARGER}

E-Mail karger@karger.com

www.karger.com/ene
(C) 2014 S. Karger AG, Basel

0014-3022/14/0724-0132\$39.50/0
Christian Kamm

Department of Neurology

VU University Medical Center

PO Box 7057, NL-1007 MB Amsterdam (The Netherlands)

E-Mail christian.kamm@insel.ch 
wards, the incidence declines, becoming rare at ages above 50 years. Across Europe, the prevalence rate of MS is about $83: 100,000$, and the mean annual incidence rate is about 4.3:100,000 [3].

MS is more common in women than in men, and has increased over the last decades from a female-to-male ratio of 1.4 in 1955 to 2.3 in 2000 . This corresponds to a lifetime risk of $2.5 \%$ in women compared to $1.4 \%$ in men $[4,5]$. The increasing overall prevalence seen in longitudinal studies is due to the longer life expectancy of MS patients and advances in diagnosing MS rather than an increased overall disease risk $[5,6]$. Life expectancy in MS patients is reduced by 7-10 years. The standardized mortality ratio is increased threefold, but this has improved over the last decades [7].

\section{Etiology}

The etiology of MS is unknown. Epidemiological data indicate that both environmental and genetic factors play a key role in the development of MS, as the prevalence of this disorder is unevenly distributed around the world [3, $5,6]$.

\section{Environmental Factors}

Higher latitude, i.e. increasing distance north or south of the equator, is correlated with an increased incidence and prevalence of MS, a correlation that, however, decreased over the past decades $[3,4,6]$.

Latitude correlates with several environmental factors, one of the strongest being sunlight exposure. MS risk is inversely correlated to sunlight exposure, and vitamin D is likely to be the responsible protective agent [8]. The effect of vitamin D supplementation in MS patients is, however, unknown, and is currently being investigated in a randomized controlled trial examining the addition of vitamin D2 to interferon (IFN)- $\beta$ - $1 \mathrm{a}$ in relapsing-remitting MS (RRMS; clinicaltrials.gov: NCT01285401).

Smoking increases MS risk in a dose-dependent manner (odds ratio, OR 1.2-1.8). Furthermore, studies indicate an association between smoking and the risk of conversion to secondary progressive MS (SPMS), disease progression and disease severity [9]. Besides smoking, vascular comorbidities are associated with the risk of disability progression in MS (OR 1.5), which increases alongside the number of vascular risk factors [10].

A single causative infectious agent for MS has not been identified and the existence of such an agent is highly unlikely. Rather, MS is an autoimmune disease that can be triggered by several microorganisms in genetically susceptible individuals. However, it is not known which infections increase, decrease or do not influence the risk of MS [11]. Recent animal studies, furthermore, suggest that the commensal gut flora could be essential in triggering immune processes in the absence of pathogenic agents [12].

The Epstein-Barr virus is an infectious agent associated with the risk of MS. Disease risk is extremely low among seronegative individuals, with $>99 \%$ of MS patients being seropositive compared to $95 \%$ in the general population [OR 0.06 (95\% CI 0.02-0.13)]. Furthermore, individuals with a history of infectious mononucleosis have a higher risk of MS than individuals without, especially if the infection occurs after adolescence [11].

The timing of exposure to environmental risk factors plays a critical role, with childhood and adolescence being the most critical time frames. This is indicated by migration studies between high- and low-risk regions. Migrants who immigrate before adolescence acquire the risk of their new region, whereas migrants who immigrate after adolescence retain the risk of their home region [13].

Furthermore, MS risk depends on the month of birth. In the northern hemisphere, MS risk is highest for individuals born in May and lowest for those born in November, which indicates that gestational environmental influences also contribute to the risk of developing MS later in life [14].

\section{Genetic Factors}

MS is not considered a hereditary disease. However, genetic factors are known to contribute to the MS risk. MS has an overall familial recurrence rate of $20 \%$. MS risk changes from $2.77 \%$ [relative risk $(\mathrm{RR})=9.2$ ] in first-degree relatives to $1.02 \%(R R=3.4)$ in second-degree relatives and $0.88 \%(R R=2.9)$ in third-degree relatives, compared to $0.3 \%$ in the general population [15]. Monozygotic twins are concordant in $24-30 \%$ of cases, compared to $3-5 \%$ in dizygotic twins, which is comparable to that of siblings [16]. Furthermore, there is no increased risk for adoptive relatives. Besides kinship, the sex of the affected family member and a parent-of-origin effect is also known to influence the MS risk $[15,17]$.

MS frequency differs between ethnicities living under comparable environmental influences, further underscoring the genetic contribution to the MS risk $[18,19]$. Genetic susceptibility to MS is associated with the human leukocyte antigen (HLA) region located on the short arm of chromosome 6 (6p21). Variations in this region can be positively or negatively associated with disease risk and 
disease course. The HLA class II region has the largest influence, with HLA-DRB1*15.01 being the single strongest susceptibility locus, conferring a threefold increase in the MS risk. Independent HLA class I and non-HLA risk foci exist as well; however, most of these exhibit weaker correlations. No variant is specific for MS. Therefore, genetic testing of individual patients is not helpful for defining a person's risk of developing MS [20, 21].

\section{Pathophysiology}

MS is characterized by CNS inflammation, demyelination, axonal injury and axonal loss. It is believed to be an autoimmune disorder, but the antigen specificity of the immune response is unknown.

During the early stages of RRMS, disease pathology is dominated by focal inflammatory white matter lesions ('plaques') characterized by primary demyelination and a variable extent of axonal loss and reactive gliosis.

Autoreactive T cells activated outside the CNS cross the blood-brain barrier and are reactivated by local antigen-presenting cells. Secretion of proinflammatory cytokines stimulates microglial cells and astrocytes, recruits additional inflammatory cells, and induces antibody production by plasma cells. This inflammatory process finally leads to tissue damage within the plaque [22]. In parallel, remyelination is possible and can repair damaged tissue to some extent. Several 'patterns of demyelination' have been distinguished based on the dominating pathophysiological mechanisms [23].

The cortex is also affected in early stages of the disease. This is observed with the presence of cortical inflammation and demyelination, cortical neurodegeneration, including neuronal, neuritic and oligodendroglial injury, and finally cortical atrophy [24]. Axonal injury is usually regarded as a secondary event to myelin damage, with the lesion developing from the myelin to the axon ('outsidein' model). However, primary axonal injury could also trigger secondary demyelination and inflammation ('inside-out' model). It is a matter of debate if one mechanism is exclusively responsible for initiating MS pathology or if both mechanisms take place simultaneously (fig. 1) [25].

In progressive disease courses, classical active white matter plaques are rare and the pathophysiology is dominated by diffuse gray and white matter atrophy. Preexisting plaques show slow and gradual expansion, characterized by low-grade inflammation and microglial activation at the plaque borders. In addition, there is diffuse injury

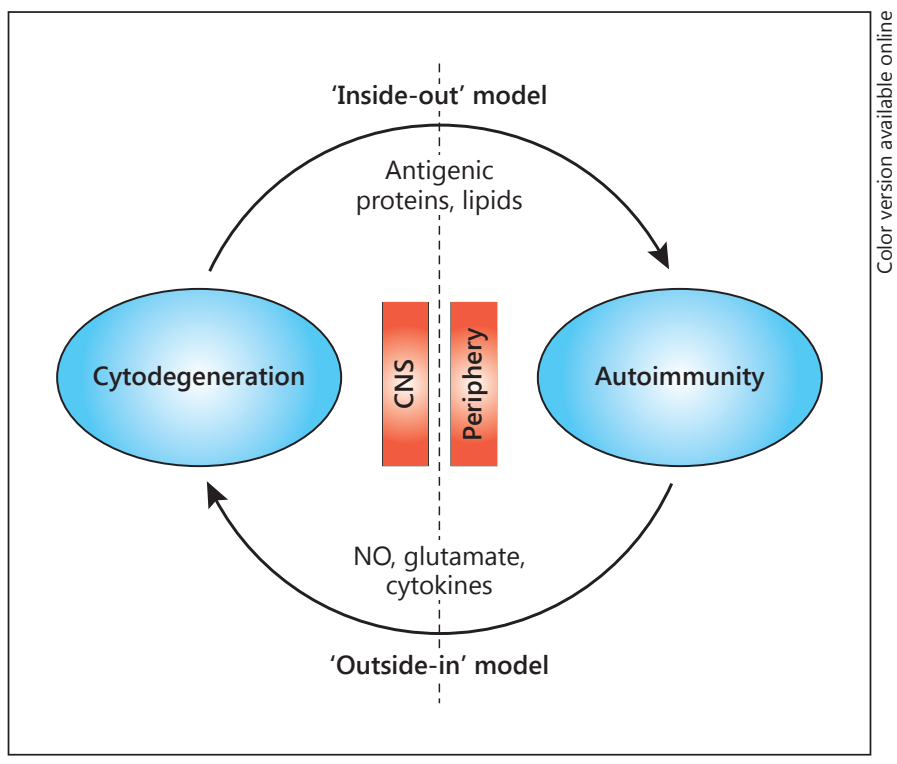

Fig. 1. Schematic contrasting the two competing hypothetical etiologies of MS (from Stys et al. [25] with permission). Traditionally, MS has been considered to be an autoimmune disease in which dysregulated autoreactive T cells in the periphery cross into the CNS and, together with macrophages and B cells, proceed to destroy various CNS elements. The resulting inflammatory reaction, which typically follows a relapsing-remitting clinical course in the initial stages, causes further demyelination and tissue injury. Such an 'outside-in' model is being challenged by a competing view that argues that the initial malfunction occurs within the CNS, similarly to other neurodegenerative disorders such as Alzheimer's and Parkinson's diseases. This alternative, 'inside-out' model argues that a primary cytodegeneration (possibly focused on the oligodendrocyte-myelin complex) is the initial event, and by releasing highly antigenic constituents, secondarily promotes an autoimmune and inflammatory response in the predisposed host, possibly further driving degeneration. $\mathrm{NO}=$ Nitric oxide.

of the normal-appearing white matter outside the plaque, consisting of inflammation and microglial activation with axonal and myelin injury followed by secondary demyelination. The diffuse ongoing destruction of gray and white matter defines the progressive nature of progressive disease courses [22].

\section{Clinical Course}

The clinical course of MS is characterized by relapses and/or disease progression. Relapses are defined as newly appearing neurological symptoms in the absence of fever or infections that last for more than $24 \mathrm{~h}$. Relapses may fully recover over days or weeks, or lead to persistent re- 
Fig. 2. Clinical courses of MS. $\mathrm{x}$-axis = Time; $\mathrm{y}$-axis = increasing disability; black areas $($ dark red in the online version $)=$ relapse; grey areas (orange in the online version) $=$ disease progression.

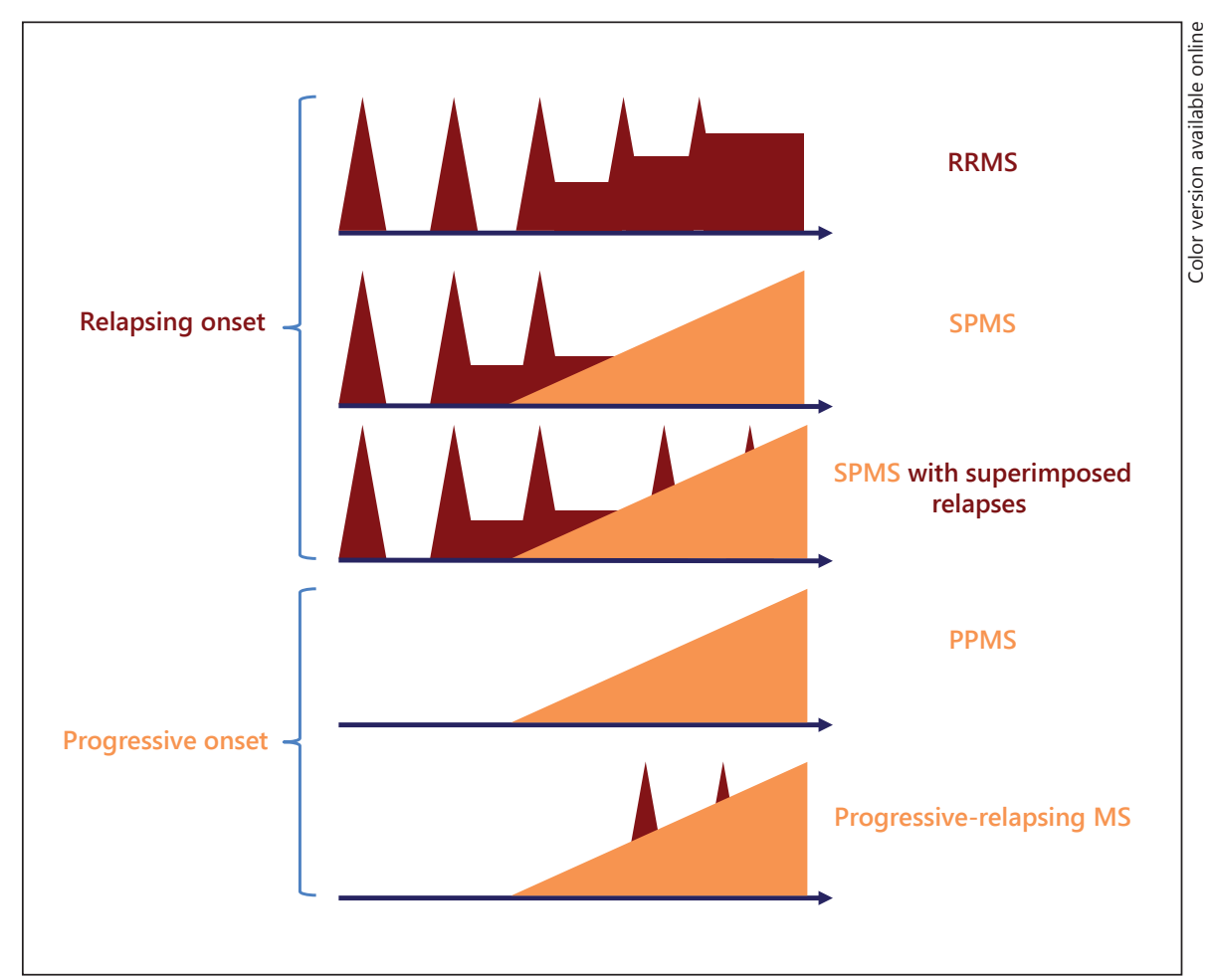

sidual deficits. Disease progression is a steady worsening of symptoms and signs over at least 6 months. Typical clinical presentations of relapses are optic neuritis (in about $20 \%$ of cases this is the initial symptom), sensory deficits or cerebellar dysfunction, whereas progressive courses are often characterized by spinal symptoms such as gait ataxia, paresis and spasticity [2]. Disability is commonly measured using the Expanded Disability Status Scale (EDSS) [26].

In $85 \%$ of patients, a relapse is the initial clinical event leading to RRMS. After a median time of approximately 19 years (at a mean age of 40 years), RRMS changes to SPMS in $75 \%$ of patients. In SPMS, a steady worsening of symptoms dominates the clinical course with superimposed relapses in $40 \%$ of patients, especially early after conversion [2].

In $15 \%$ of patients, the disease is progressive from the onset (primary progressive MS, PPMS), with a mean age of onset of 40 years. Amongst these patients, $40 \%$ experience superimposed relapses (progressive-relapsing MS; fig. 2) [27]. Clinical symptoms are dominated by dysfunctions of the corticospinal tracts and disease courses are more severe compared to initially relapsing forms of MS. For example, an EDSS score of 6, i.e. the need for unilateral support to walk at least $100 \mathrm{~m}$, is reached in 7 years in PPMS compared to 12.5 years in SPMS patients [2]. However, the disease course is not predictable for the individual patient [28].

\section{Diagnosis}

The diagnosis of MS is based on the demonstration of MS-typical CNS lesions disseminated in space (DIS) and time (DIT) based upon clinical findings alone or a combination of clinical and MRI findings. In 2010, the socalled McDonald criteria, first published in 2001, were revised for the second time by the International Panel on Diagnosis of MS based on new evidence and consensus to facilitate earlier diagnosis of MS and to increase the sensitivity and specificity of diagnosis [29]. DIS lesions detected using MRI can now be used for diagnosis, with at least one T2 lesion in two out of four CNS regions considered typical of MS. For DIS, symptomatic lesions in patients with brainstem and/or spinal cord symptoms are excluded. DIT lesions detected using MRI can be demonstrated by the presence of a new T2 and/or gadolinium (Gd)-enhancing lesion(s) on follow-up MRI, with reference to a baseline scan irrespective of the timing of the baseline MRI, or by the simultaneous presence of asymp- 
Table 1. The 2010 McDonald criteria for the diagnosis of MS

\begin{tabular}{|c|c|}
\hline Clinical presentation & Additional data needed for MS diagnosis \\
\hline $\begin{array}{l}\geq 2 \text { attacks, objective clinical evidence of } \geq 2 \text { lesions } \\
\text { or objective clinical evidence of } 1 \text { lesion with } \\
\text { reasonable historical evidence of a prior attack }\end{array}$ & None \\
\hline$\geq 2$ attacks, objective clinical evidence of 1 lesion & $\begin{array}{l}\text { DIS demonstrated by: } \\
-\quad \geq 1 \mathrm{~T} 2 \text { lesion }{ }^{\mathrm{a}} \text { in at least } 2 \text { out of } 4 \text { MS-typical regions of the CNS } \\
\quad \text { (periventricular, juxtacortical, infratentorial or spinal cord }{ }^{\mathrm{b}} \text { ), or } \\
-\quad \text { Await a further clinical attack implicating a different CNS site }\end{array}$ \\
\hline 1 attack, objective clinical evidence of $\geq 2$ lesions & $\begin{array}{l}\text { DIT demonstrated by: } \\
\text { - Simultaneous presence of asymptomatic Gd-enhancing and } \\
\text { non-enhancing lesions at any time, or } \\
\text { - A new T2 and/or Gd-enhancing lesion(s) on follow-up MRI, irrespective } \\
\text { of its timing with reference to a baseline scan, or } \\
\text { - Await a second clinical attack }\end{array}$ \\
\hline $\begin{array}{l}1 \text { attack, objective clinical evidence of } 1 \text { lesion } \\
\text { (clinically isolated syndrome) }\end{array}$ & Demonstration of DIS and DIT (see above) \\
\hline $\begin{array}{l}\text { Insidious neurological progression suggestive of MS } \\
\text { (PPMS) }\end{array}$ & $\begin{array}{l}\text { 1 year of disease progression (retrospectively or prospectively determined) } \\
\text { plus } 2 \text { out of } 3 \text { of the following criteriac: } \\
\text { 1. Evidence for DIS in the brain based on } \geq 1 \mathrm{~T} 2 \text { lesion in the } \\
\text { MS-characteristic regions (periventricular, juxtacortical or infratentorial) } \\
\text { 2. Evidence for DIS in the spinal cord based on } \geq 2 \mathrm{~T} 2 \text { lesions in the cord } \\
\text { 3. Positive cerebrospinal fluid (isoelectric focusing evidence of oligoclonal } \\
\text { bands and/or elevated IgG index) }\end{array}$ \\
\hline
\end{tabular}

Based on Polman et al. [29], used with permission.

${ }^{a} \mathrm{Gd}$ enhancement of lesions is not required for DIS. ${ }^{\mathrm{b}}$ If a subject has a brainstem or spinal cord syndrome, the symptomatic lesions are excluded from the criteria and do not contribute to lesion count. ${ }^{c}$ Gd-enhancing lesions are not required; symptomatic lesions are excluded from consideration in subjects with brainstem or spinal cord syndromes.

tomatic Gd-enhancing and non-enhancing lesions at any time (table 1). Therefore, at earliest, RRMS can be diagnosed after a single relapse with a single MRI showing asymptomatic Gd-enhancing and non-enhancing lesions that are disseminated in space.

For the diagnosis of PPMS, 1 year of disease progression and 2 out of 3 criteria regarding the presence of lesions in typical brain regions, DIS in the spinal cord and positive cerebrospinal fluid findings are required (table 1).

In general, at least one clinical attack must be corroborated by findings on neurological examination, visual evoked potentials or MRI consistent with the clinical presentation. Furthermore, the exclusion of alternative diagnoses is mandatory when applying the criteria. Besides the correct interpretation of the clinical symptoms and signs as well as the MRI, additional assessments such as lumbar puncture, blood tests and visual evoked potentials are useful for excluding other diseases and to support the diagnosis of MS.

\section{Therapeutic Management}

There is no cure for MS. In principle, the therapeutic management of MS patients can be divided into relapse treatment, disease-modifying treatment and symptomatic treatment.

\section{Relapse Treatment}

Relapses are commonly treated with intravenous methylprednisolone at a dose of $1 \mathrm{~g} /$ day or $500 \mathrm{mg} /$ day for 3-5 days with or without oral tapering. Alternatively, the treatment can be administered orally in equal doses [30]. In case of persistent severe relapse symptoms, a second cycle can be applied with dosages up to $2 \mathrm{~g} /$ day for 5 days. If the second cycle is also not effective, plasmapheresis may be considered [31]. 
Table 2. Currently approved therapies (Europe)

\begin{tabular}{|c|c|c|c|c|}
\hline Drug (brand name) & Approval & Indication & Dosage/application & Side effects \\
\hline $\begin{array}{l}\text { Basic therapeutics } \\
\text { IFN- } \beta \text { - } 1 \mathrm{~b} \\
\text { (Betaferon/Betaseron) }\end{array}$ & 1995 & $\begin{array}{l}\text { CIS } \\
\text { RRMS, SPMS }\end{array}$ & $\begin{array}{l}250 \mu \mathrm{g} \text { s.c. } \\
\text { every other day }\end{array}$ & $\begin{array}{l}\text { Flu-like symptoms, injection site } \\
\text { reactions, elevated liver enzymes }\end{array}$ \\
\hline $\begin{array}{l}\text { IFN- } \beta-1 \mathrm{a} \\
(\text { Avonex) }\end{array}$ & 1997 & $\begin{array}{l}\text { CIS } \\
\text { RRMS }\end{array}$ & $30 \mu \mathrm{g}$ i.m. once weekly & $\begin{array}{l}\text { Flu-like symptoms, injection site } \\
\text { reactions, elevated liver enzymes }\end{array}$ \\
\hline $\begin{array}{l}\text { Glatiramer acetate } \\
\text { (Copaxone) }\end{array}$ & 1997 & $\begin{array}{l}\text { CIS } \\
\text { RRMS }\end{array}$ & $20 \mathrm{mg}$ s.c. daily & $\begin{array}{l}\text { Injection site reactions, immediate } \\
\text { postinjection systemic reaction }\end{array}$ \\
\hline $\begin{array}{l}\text { IFN- } \beta-1 \mathrm{a} \\
\text { (Rebif) }\end{array}$ & 2002 & $\begin{array}{l}\text { CIS } \\
\text { RRMS } \\
\text { SPMS }\end{array}$ & $44 \mu \mathrm{g}$ s.c. three times weekly & $\begin{array}{l}\text { Flu-like symptoms, injection site } \\
\text { reactions, elevated liver enzymes }\end{array}$ \\
\hline $\begin{array}{l}\text { Teriflunomide } \\
\text { (Aubagio) }\end{array}$ & 2013 & RRMS & $\begin{array}{l}7 \mathrm{mg} / \text { day p.o. } \\
14 \mathrm{mg} / \text { day p.o. }\end{array}$ & Diarrhea, nausea, hair thinning \\
\hline $\begin{array}{l}\text { Escalation therapy } \\
\text { Natalizumab } \\
\text { (Tysabri) }\end{array}$ & 2007 & $\begin{array}{l}\text { Highly active } \\
\text { RRMS }\end{array}$ & $300 \mathrm{mg}$ i.v. every 4 weeks & Allergic infusion reactions, PML \\
\hline $\begin{array}{l}\text { Fingolimod } \\
\text { (Gilenya) }\end{array}$ & 2011 & RRMS & $0.5 \mathrm{mg}$ p.o. once daily & $\begin{array}{l}\text { (Brady-)arrhythmias, } \mathrm{FEV}_{1} \text { reduction, } \\
\text { macular edema }\end{array}$ \\
\hline $\begin{array}{l}\text { Mitoxantrone } \\
\text { (Novantron, } \\
\text { Mitoxantron Ebewe) }\end{array}$ & 2002 & $\begin{array}{l}\text { Highly active } \\
\text { RRMS or SPMS }\end{array}$ & $\begin{array}{l}12 \mathrm{mg} / \mathrm{m}^{2} \mathrm{BS} \text { i.v. every } 3 \text { months; } \\
\text { maximum lifetime cumulative dose: } \\
140 \mathrm{mg} / \mathrm{m}^{2} \mathrm{BS}\end{array}$ & $\begin{array}{l}\text { Nausea, vomiting, alopecia, } \\
\text { therapy-related leukemia, cardiotoxicity }\end{array}$ \\
\hline
\end{tabular}

CIS = Clinically isolated syndrome; $\mathrm{FEV}_{1}=$ forced expiratory volume in $1 \mathrm{~s} ; \mathrm{BS}=$ body surface. Gilenya is approved as basic therapy in Switzerland.

\section{Disease-Modifying Treatment}

Several drugs are available to potentially ameliorate the disease course in case the clinical course is dominated by relapses, as for the clinically isolated syndrome, RRMS and occasionally SPMS. The indication depends mainly on the clinical course, disease stage and disease activity (table 2). In general, therapy should be initiated as early as possible [32]. So far, no drug has been approved for the treatment of PPMS.

First-line basic therapy is distinguished from secondline escalation therapies. Usually, treatment is started with basic therapeutics and the patient monitored clinically with subsequent MRI. In case of stable disease and well-tolerated treatment, therapy is continued. In case of ongoing clinical and/or radiological disease activity and/ or relevant side effects, escalation therapy can be initiated. In general, patients with $\geq 1$ relapse per year, absence of complete recovery from relapses, sustained EDSS progression of $\geq 1$ and MRI progression with or without clinical signs are considered as 'treatment nonresponders', justifying the transition from basic to escalation therapy.
While this procedure is well established for inflammatory treatment nonresponders' with ongoing inflammatory disease activity (relapses, new T2 or Gd-enhancing lesions), effective escalation strategies for noninflammatory treatment nonresponders with disease progression without inflammatory disease activity are lacking, as no drug sufficiently ameliorates the degenerative part of the disease.

Besides its use as second-line therapy, escalation therapeutics can also be considered as first-line therapy in very active MS. An overview of the currently approved drugs in Europe is given in table 2.

\section{Basic Therapeutics}

IFN- $\beta$ (Avonex ${ }^{\circledR}$, Betaferon ${ }^{\circledR} /$ Betaseron $^{\circledR}$ and Rebif ${ }^{\circledR}$ ) and glatiramer acetate (Copaxone ${ }^{\circledR}$ ) are immunomodulators used as first-line therapeutics with more than 20 years of experience. They reduce the annualized relapse rate (ARR) by approximately $30 \%$ and do not cause severe side effects [32]. 
Teriflunomide (Aubagio ${ }^{\circledR}$ ) is an oral drug that reduces the activity of the mitochondrial enzyme dihydroorotate dehydrogenase, which is crucial in pyrimidine synthesis and is necessary for T-lymphocyte proliferation. In a pivotal trial, it reduced ARR by $31 \%$ compared to placebo and had a favorable safety profile [33].

Fingolimod $\left(\right.$ Gilenya $\left.^{\circledR}\right)$ is approved as basic therapy in Switzerland, and in all other countries as escalation therapy. Therefore, it is described in the section below.

\section{Escalation Therapy}

In general, the currently available escalation therapeutics are more potent than the basic therapeutics (IFN- $\beta$ / glatiramer acetate); however, these agents have potentially serious side effects.

Natalizumab (Tysabri ${ }^{\circledR}$ ) is a humanized monoclonal anti-a4-integrin antibody that inhibits leukocytes from entering the brain via the blood-brain barrier. It reduced the ARR by $68 \%$ in a pivotal trial [34]. The most clinically significant complication was progressive multifocal leukoencephalopathy (PML), a JC virus infection of the brain that is lethal in $20 \%$ of patients. If patients survive PML, neurological impairments can be severe (30\%), moderate $(50 \%)$ or mild (15\%), and in few cases absent [35]. PML differs clinically from MS relapses, and in the presence of symptoms suspicious of PML, brain MRI and lumbar puncture including JC virus PCR are mandatory [36]. Overall, PML occurs in approximately 2.6 per 1,000 natalizumab-treated patients. However, risk stratification can be performed depending on three risk factors: anti-JC virus antibody status, treatment duration (more or less than 2 years) and prior immunosuppressive therapy. Risks range from $<1: 50,000$ (no risk factors) to 1:56 (all risk factors) [35]. Furthermore, the newly developed anti-JC virus antibody index, which is corollary to the antibody titer, might be useful to further predict PML risk in JC-positive patients. The use of natalizumab is restricted to RRMS patients with high disease activity despite basic therapy or in treatment-naive patients with highly active RRMS (for details, please see www.ema.europa.eu or www.fda.gov).

Fingolimod (Gilenya) is an immunomodulatory and immunosuppressive oral drug. It binds to sphingosine1-phosphate receptors and inhibits $B$ and $T$ cells from egressing the lymph nodes. In pivotal trials, fingolimod reduced ARR by $54 \%$ compared to placebo and $52 \%$ compared to IFN- $\beta$-1a (Avonex) $[37,38]$. Important side effects are transient cardiac arrhythmias at therapy start and macular edema mostly within the first 6 months. However, there have been case reports on possible drug- related serious cardiac side effects, including asystole and sustained bradycardia as well as sudden unexpected death possibly due to ventricular arrhythmia $[39,40]$. The approved dosage $(0.5 \mathrm{mg})$ was not clearly related to an increased risk of infections or tumors. However, the longterm safety profile is unknown and 2 fatal herpes infections occurred in the 1.25-mg group [37, 38]. Due to these side effects and safety concerns, several contraindications apply and extensive safety monitoring is necessary before and during first-dose application as well as during therapy (for details please see www.ema.europa.eu or www. fda.gov).

Mitoxantrone (Novantron ${ }^{\circledR}$ and Mitoxantron Ebe$\left.\mathrm{we}^{\circledR}\right)$ is an immunosuppressive anthracenedione derivative approved for the treatment of worsening RRMS, SPMS and progressive-relapsing MS, either as first-line therapy or in case of failure or intolerance to previous immunomodulatory therapy [41]. Treatment is restricted to a cumulative total life dose of $140 \mathrm{mg} / \mathrm{m}^{2}$ body surface due to risk of cardiac toxicity. Therapy-related acute leukemia can occur, with a relative risk of $0.21 \%$. Therefore, safety assessments, such as regular echocardiographic examinations and blood tests, are mandatory during and after treatment [42].

\section{Symptomatic Treatment}

MS patients may suffer from various neurologic sequelae such as fatigue, depression, spasticity, tremor, ataxia, seizures, pain, sleep disorders, nystagmus, sexual dysfunction, and urogenital and bowel disorders that can be addressed with drugs and/or physical and occupational therapy. This is critical in the care of MS patients in order to improve quality of life and the ability to work. A detailed review on symptomatic treatment in MS is given by de Sa et al. [43].

\section{Future Perspectives}

Several new drugs have recently demonstrated their efficacy in RRMS in randomized controlled phase III trials, and have been recently approved in some countries or their approval can be expected in the near future. An overview of the pivotal trials, including dosage, application, efficacy (ARR) and side effects, is given in table 3.

Dimethyl fumarate (Tecfidera ${ }^{\circledR}$ ) was approved by the US Food and Drug Administration in March 2013 for the treatment of RRMS. It is protective against oxidative stress-related neuronal death and myelin damage mediated through activation of the nuclear factor (erythroid- 
Table 3. Future therapies: published phase III, randomized, controlled trials

\begin{tabular}{|c|c|c|c|c|c|}
\hline & name/reference No. & comparator & dosage/application & ARR (RRR) & side effects \\
\hline $\begin{array}{l}\text { Laquinimod } \\
\text { (Nerventra) }\end{array}$ & ALLEGRO [49] & Placebo & 0.6 mg/day p.o. & $-23 \%$ & Elevated liver enzymes \\
\hline
\end{tabular}

\begin{tabular}{|c|c|c|c|c|c|}
\hline \multicolumn{6}{|c|}{ Humanized monoclonal antibodies } \\
\hline $\begin{array}{l}\text { Alemtuzumab } \\
\text { (Lemtrada) }\end{array}$ & $\begin{array}{l}\text { CARE-MS I [45] } \\
\text { CARE-MS II [46] }\end{array}$ & $\begin{array}{l}\text { Rebif } \\
\text { Rebif }\end{array}$ & $\begin{array}{l}12 \mathrm{mg} \text { i.v. for } 5 \text { days and } \\
\text { after } 12 \text { months for } 3 \text { days, } \\
\text { in both studies }\end{array}$ & $\begin{array}{l}-54.9 \% \\
-49.4 \%\end{array}$ & $\begin{array}{l}\text { Infusion-associated reactions; } \\
\text { secondary autoimmune diseases } \\
\text { (thyroid disorders, immune } \\
\text { thrombocytopenia) }\end{array}$ \\
\hline Daclizumab & SELECT [50] & Placebo & $\begin{array}{l}150 \mathrm{mg} \text { s.c. monthly } \\
300 \mathrm{mg} \text { s.c. monthly }\end{array}$ & $\begin{array}{l}-54 \% \\
-50 \%\end{array}$ & $\begin{array}{l}\text { Elevated liver enzymes, infections, } \\
\text { cutaneous reaction }\end{array}$ \\
\hline
\end{tabular}

ARR is the primary study endpoint. $R R R=R R$ reduction; Tecfidera was approved in March 2013 by the FDA for the treatment of RRMS; Lemtrada was approved in September 2013 by the EMA for the treatment of active RRMS.

derived 2)-like 2 (Nrf2) antioxidant response pathway and additionally has anti-inflammatory properties. Dimethyl fumarate appears to have a good efficacy/safety profile [44].

Alemtuzumab (Lemtrada ${ }^{\circledR}$ ) was approved in September 2013 by the European Medicines Agency for the treatment of active RRMS. It is a humanized anti-CD52 monoclonal antibody that leads to a long-lasting depletion of circulating $\mathrm{T}$ and $\mathrm{B}$ lymphocytes. Besides good efficacy shown against an active comparator, there are relevant side effects dominated by secondary autoimmune diseases, including thyroid disorders and immune thrombocytopenia $[45,46]$.

With respect to the growing number of therapeutic agents with different modes of action, application, efficacy, tolerability and safety profiles, a future challenge will be to choose the most efficacious, safe and tolerable drug for the individual patient. Biomarkers that help to predict these issues in the individual patient would therefore be of importance [47].

Furthermore, all approved and upcoming drugs predominantly exert their effects on the inflammatory disease process. No drugs so far substantially improve the degenerative disease process, explaining the lack of efficacy in progressive disease courses. The real breakthrough in the treatment of MS will be in identifying treatments that prevent neurodegeneration as well as support remyelination and repair of damaged tissue [48].

\section{Disclosure Statement}

Christian P. Kamm has received compensation for activities as a consultant/speaker from Genzyme, Teva, Novartis, Merck Serono, Biogen Idec and Bayer. Bernard M.J. Uitdehaag has received consultancy fees from Novartis, Merck Serono, Biogen Idec and Danone Research. Chris H. Polman has received compensation for activities from Actelion, Biogen Idec, Bayer Schering, GlaxoSmithKline, Merck Serono, MorphoSys AG, Novartis, TEVA, UCB and Roche as a consultant/speaker, and research support from Biogen Idec, Bayer Schering, GlaxoSmithKline, Merck Serono, Novartis, TEVA, UCB and Roche.

References 
-6 Evans C, Beland SG, Kulaga S, Wolfson C, Kingwell E, Marriott J, Koch M, Makhani N, Morrow S, Fisk J, Dykeman J, Jetté N, Pringsheim T, Marrie RA: Incidence and prevalence of multiple sclerosis in the Americas: a systematic review. Neuroepidemiology 2013;40: 195-210.

-7 Grytten Torkildsen N, Lie SA, Aarseth JH, 22 Nyland H, Myhr KM: Survival and cause of death in multiple sclerosis: results from a 50year follow-up in Western Norway. Mult Scler 2008;14:1191-1198.

-8 Ascherio A, Munger KL, Simon KC: Vitamin $\mathrm{D}$ and multiple sclerosis. Lancet Neurol 2010; 9:599-612.

9 Wingerchuk DM: Smoking: effects on multiple sclerosis susceptibility and disease progression. Ther Adv Neurol Disord 2012;5: $13-22$.

10 Marrie RA, Rudick R, Horwitz R, Cutter G, Tyry T, Campagnolo D, Vollmer T: Vascular comorbidity is associated with more rapid disability progression in multiple sclerosis. Neurology 2010;74:1041-1047.

-11 Ascherio A, Munger KL: Environmental risk factors for multiple sclerosis. Part I. The role of infection (review). Ann Neurol 2007;61: 288-299.

12 Berer K, Mues M, Koutrolos M, Rasbi ZA, Boziki M, Johner C, Wekerle H, Krishnamoorthy G: Commensal microbiota and myelin autoantigen cooperate to trigger autoimmune demyelination. Nature 2011;479: 538-541.

13 Elian M, Nightingale S, Dean G: Multiple sclerosis among United Kingdom-born children of immigrants from the Indian subcontinent, Africa and the West Indies. J Neurol Neurosurg Psychiatry 1990;53:906-911.

-14 Willer CJ, Dyment DA, Sadovnick AD, Rothwell PM, Murray TJ, Ebers GC; Canadian Collaborative Study Group: Timing of birth and risk of multiple sclerosis: population based study. BMJ 2005;330:120.

15 Robertson NP, Fraser M, Deans J, Clayton D, Walker N, Compston DA: Age-adjusted recurrence risks for relatives of patients with multiple sclerosis. Brain 1996;119:449-455.

-16 Hansen T, Skytthe A, Stenager E, Petersen HC, Brønnum-Hansen H, Kyvik KO: Concordance for multiple sclerosis in Danish twins: an update of a nationwide study. Mult Scler 2005; 11:504-510.

17 Ebers GC, Sadovnick AD, Dyment DA, Yee IM, Willer CJ, Risch N: Parent-of-origin effect in multiple sclerosis: observations in halfsiblings. Lancet 2004;363:1773-1774.

18 Svenson LW, Warren S, Warren KG, Metz LM, Patten SB, Schopflocher DP: Prevalence of multiple sclerosis in First Nations people of Alberta. Can J Neurol Sci 2007;34:175-180.

19 Williamson DM, Henry JP, Schiffer R, Wagner L: Prevalence of multiple sclerosis in 19 Texas counties, 1998-2000. J Environ Health 2007;69:41-55.
20 Gourraud PA, Harbo HF, Hauser SL, Baranzini SE: The genetics of multiple sclerosis: an up-to-date review. Immunol Rev 2012;248: 87-103.

21 Lin R, Charlesworth J, van der Mei I, Taylor BV: The genetics of multiple sclerosis (review). Pract Neurol 2012;12:279-288.

2 Lassmann H, Brück W, Lucchinetti CF: The immunopathology of multiple sclerosis: an overview (review). Brain Pathol 2007;17:210218.

23 Lassmann H, Brück W, Lucchinetti C: Heterogeneity of multiple sclerosis pathogenesis: implications for diagnosis and therapy (review). Trends Mol Med 2001;7:115-121.

24 Lucchinetti CF, Popescu BF, Bunyan RF, Moll NM, Roemer SF, Lassmann H, Brück W, Parisi JE, Scheithauer BW, Giannini C, Weigand SD, Mandrekar J, Ransohoff RM: Inflammatory cortical demyelination in early multiple sclerosis. N Engl J Med 2011;365:2188-2197.

25 Stys PK, Zamponi GW, van Minnen J, Geurts JJ: Will the real multiple sclerosis please stand up (review)? Nat Rev Neurosci 2012;13:507514, erratum 2012;13:597.

26 Kurtzke JF: Rating neurologic impairment in multiple sclerosis: an expanded disability status scale (EDSS). Neurology 1983;33:14441452.

27 Lublin FD, Reingold SC: Defining the clinical course of multiple sclerosis: results of an international survey. National Multiple Sclerosis Society (USA) Advisory Committee on Clinical Trials of New Agents in Multiple Sclerosis. Neurology 1996;46:907-911.

28 Vukusic S, Confavreux C: Natural history of multiple sclerosis: risk factors and prognostic indicators (review). Curr Opin Neurol 2007; 20:269-274.

29 Polman CH, Reingold SC, Banwell B, Clanet M, Cohen JA, Filippi M, Fujihara K, Havrdova E, Hutchinson M, Kappos L, Lublin FD, Montalban X, O'Connor P, Sandberg-Wollheim $\mathrm{M}$, Thompson AJ, Waubant E, Weinshenker B, Wolinsky JS: Diagnostic criteria for multiple sclerosis: 2010 revisions to the McDonald criteria (review). Ann Neurol 2011;69:292-302.

30 Burton JM, O'Connor PW, Hohol M, Beyene $\mathrm{J}$ : Oral versus intravenous steroids for treatment of relapses in multiple sclerosis (review). Cochrane Database Syst Rev 2012; 12:CD006921.

31 Cortese I, Chaudhry V, So YT, Cantor F, Cornblath DR, Rae-Grant A: Evidence-based guideline update: plasmapheresis in neurologic disorders: report of the Therapeutics and Technology Assessment Subcommittee of the American Academy of Neurology (review). Neurology 2011;76:294-300.

32 McGraw CA, Lublin FD: Interferon beta and glatiramer acetate therapy. Neurotherapeutics 2013;10:2-18.
33 O'Connor P, Wolinsky JS, Confavreux C, Comi G, Kappos L, Olsson TP, Benzerdjeb H, Truffinet P, Wang L, Miller A, Freedman MS; TEMSO Trial Group: Randomized trial of oral teriflunomide for relapsing multiple sclerosis. TEMSO Trial Group. N Engl J Med 2011;365:1293-1303.

34 Polman CH, O'Connor PW, Havrdova E, Hutchinson M, Kappos L, Miller DH, Phillips JT, Lublin FD, Giovannoni G, Wajgt A, Toal M, Lynn F, Panzara MA, Sandrock AW; AFFIRM Investigators: A randomized, placebocontrolled trial of natalizumab for relapsing multiple sclerosis. N Engl J Med 2006;354: 899-910.

35 Baldwin KJ, Hogg JP: Progressive multifocal leukoencephalopathy in patients with multiple sclerosis. Curr Opin Neurol 2013;26:318323.

36 Kappos L, Bates D, Hartung HP, Havrdova E Miller D, Polman $\mathrm{CH}$, Ravnborg M, Hauser SL, Rudick RA, Weiner HL, O'Connor PW, King J, Radue EW, Yousry T, Major EO, Clifford DB: Natalizumab treatment for multiple sclerosis: recommendations for patient selection and monitoring (review). Lancet Neurol 2007;6:431-441.

-37 Kappos L, Radue EW, O’Connor P, Polman C, Hohlfeld R, Calabresi P, Selmaj K, Agoropoulou C, Leyk M, Zhang-Auberson L, Burtin P; FREEDOMS Study Group: A placebo-controlled trial or oral fingolimod in relapsing remitting multiple sclerosis. N Engl J Med 2010; 362:387-401.

38 Cohen JA, Barkhof F, Comi G, Hartung HP, Khatri BO, Montalban X, Pelletier J, Capra R, Gallo P, Izquierdo G, Tiel-Wilck K, de Vera A, Jin J, Stites T, Wu S, Aradhye S, Kappos L; TRANSFORMS Study Group: Oral fingolimod or intramuscular interferon for relapsing multiple sclerosis. N Engl J Med 2010;362: 402-415.

39 Espinosa PS, Berger JR: Delayed fingolimodassociated asystole. Mult Scler 2011;17:13871389.

40 Lindsey JW, Haden-Pinneri K, Memon NB, Buja LM: Sudden unexpected death on fingolimod. Mult Scler 2012;18:1507-1508.

41 Hartung HP, Gonsette R, König N, Kwiecinski $\mathrm{H}$, Guseo A, Morrissey SP, Krapf $\mathrm{H}$, Zwingers T; Mitoxantrone in Multiple Sclerosis Study Group (MIMS): Mitoxantrone in progressive multiple sclerosis: a placebo-controlled, double-blind, randomised, multicentre trial. Lancet 2002;360:2018-2025.

42 Neuhaus O, Kieseier BC, Hartung HP: Therapeutic role of mitoxantrone in multiple sclerosis (review). Pharmacol Ther 2006;109: 198-209.

43 de Sa JC, Airas L, Bartholome E, Grigoriadis N, Mattle H, Oreja-Guevara C, O'Riordan J, Sellebjerg F, Stankoff B, Vass K, Walczak A, Wiendl H, Kieseier BC: Symptomatic therapy in multiple sclerosis: a review for a multimodal approach in clinical practice. Ther Adv Neurol Disord 2011;4:139-168. 
44 Gold R, Kappos L, Arnold DL, Bar-Or A, Giovannoni G, Selmaj K, Tornatore C, Sweetser MT, Yang M, Sheikh SI, Dawson KT; DEFINE Study Investigators: Placebo-controlled phase 3 study of oral BG-12 for relapsing multiple sclerosis. N Engl J Med 2012;367:10981107, erratum p 2362.

45 Cohen JA, Coles AJ, Arnold DL, Confavreux C, Fox EJ, Hartung HP, Havrdova E, Selmaj KW, Weiner HL, Fisher E, Brinar VV, Giovannoni G, Stojanovic M, Ertik BI, Lake SL, Margolin DH, Panzara MA, Compston DA; CARE-MS I Investigators: Alemtuzumab versus interferon beta la as first-line treatment for patients with relapsing-remitting multiple sclerosis: a randomised controlled phase 3 trial. Lancet 2012;380:1819-1828.
6 Coles AJ, Twyman CL, Arnold DL, Cohen JA, Confavreux C, Fox EJ, Hartung HP, Havrdova E, Selmaj KW, Weiner HL, Miller T, Fisher E, Sandbrink R, Lake SL, Margolin DH, Oyuela P, Panzara MA, Compston DA; CARE-MS II Investigators: Alemtuzumab for patients with relapsing multiple sclerosis after disease-modifying therapy: a randomised controlled phase 3 trial. Lancet 2012;380: 1829-1839.

47 Katsavos S, Anagnostouli M: Biomarkers in multiple sclerosis: an up-to-date overview. Mult Scler Int 2013;2013:340508.

48 Van der Walt A, Butzkueven H, Kolbe S, Marriott M, Alexandrou E, Gresle M, Egan G, Kilpatrick T: Neuroprotection in multiple sclerosis: a therapeutic challenge for the next decade. Pharmacol Ther 2010;126:82-93.
9 Comi G, Jeffery D, Kappos L, Montalban X, Boyko A, Rocca MA, Filippi M; ALLEGRO Study Group: Placebo-controlled trial of oral laquinimod for multiple sclerosis. $\mathrm{N}$ Engl J Med 2012;366:1000-1009.

50 Gold R, Giovannoni G, Selmaj K, Havrdova E, Montalban X, Radue EW, Stefoski D, Robinson R, Riester K, Rana J, Elkins J, O’Neill G; SELECT study investigators: Daclizumab high-yield process in relapsing-remitting multiple sclerosis (SELECT): a randomised, double-blind, placebo-controlled trial. Lancet 2013;381:2167-2175. 